\title{
Posisi Ulama dalam Pemilihan Gubenur Jawa Timur Perspektif Fiqh Siyasah
}

\author{
Roikhatul Hamidah \\ \begin{tabular}{l|l} 
ikha_hmd21@gmail.com & $\begin{array}{l}\text { DPW PPKB Jawa Timur } \\
\text { Ds. Kajeksan Kec. Tulangan Ka6. } \\
\text { Sidoarjo, Indonesia }\end{array}$
\end{tabular}
}

\begin{abstract}
This paper aims to find out the Ulama's standpoint in the practice of Election of Governors from fiqh siyasah perspective. The results of the study concluded that the election of governor in East Java conducted through direct election by the people. The influence of Ulama in the election of governors and deputy governors of East Java to the people drawn the interest of politicians. It is because the Ulama have the legality, influence, and social capital that are the parameters that can influence the tide of votes in the election of the Governor of East Java that is still heavily associated with Pesantren culture. In Islam, there is no prohibition for Ulama to take part in political life as the Prophet besides being the bearer of the treatise of Allah also become as umara'. At the time of khulafaur Rasidin almost every line of sUlama held the government position. The most important thing is to be able to control the umara/government in carrying out its duties as the people's representative. This kind of indicator will elevate the image of the Ulama as a servant of God among other creatures.
\end{abstract}

Keywords: the election of governor of East Java, Ulama influence, Fiqh Siyasah

\begin{abstract}
Abstrak: Tulisan ini bertujuan mengetahui posisi ulama dalam Pemilihan Gubernur dalam perspektif fiqh siyasah. Hasil penelitian menyimpulkan bahwa Mekanisme pengisian jabatan kepala daerah di Jawa Timur dengan sistem pemilihan langsung oleh rakyat. Posisi ulama dalam pemilihan gubernur dan wakil gubernur Jawa Timur diperebutkan oleh para politisi. Karena ulama mempunyai legalitas, pengaruh dan modal sosial sebagai parameter yang dapat mempengaruhi pasang-surutnya perolehan suara dalam Pemilihan Gubernur Jawa Timur yang masih kental dengan kultur pesantren. Dalam Islam tidak ada larangan ulama untuk mengambil bagian dalam kehidupan berpolitik, karena Nabi disamping sebagai pembawa risalah Allah juga merangkap sebagai umara'. Pada masa khulafaur
\end{abstract}


rasidin hampir di semua lini ulama menduduki jabatan pemerintah. yang paling penting adalah dapat menjadi kontrol umara/pemerintah dalam menjalankan tugasnya sebagai wakil rakyat. Indikator semacam ini akan mengangkat citra ulama sebagai hamba Allah, yang paling patut di antara hamba-hambanya.

Kata kunci: Pemilihan Gubernur Jawa Timur, posisi dan pengaruh ulama, dan fiqh siyasah.

\section{Pendahuluan}

Reformasi 1998 yang ditandai dengan tumbangnya rezim orde baru telah menjadikan kondisi panggung perpolitikan di Indonesia mengalami perubahan secara drastis. Salah satu perubahan yang menarik untuk dicermati di era transisi tersebut adalah berubahnya sistem komando hubungan pemerintahan pusat dan pemerintahan daerah, dari sentralisasi menjadi desentralisasi.

Perubahan yang signifikan dalam pemerintahan daerah di antaranya ialah tentang pemilihan kepala daerah provinsi, kabupaten/kota yang dilaksanakan pemilihannya secara langsung oleh rakyat. Mekanisme pemilihan kepala dan wakil kepala daerah secara langsung merupakan intepretasi dari Amandemen UUD 1945.

Era reformasi tidak hanya menjadi awal bagi bangsa ini untuk menapaki masa baru yang lebih dinamis, namun juga mampu menghadirkan suatu kondisi di mana ruang publik dapat dimasuki seluruh lapisan masyarakat, tidak terkecuali kalangan ulama dan tokoh-tokoh sipil yang sebelumnya, eksistensinya nyaris terpinggirkan di setiap proses pengambilan keputusan politik maupun pelaksanaan pemerintahan di masa Orde Baru. Kecuali beberapa ulama yang loyal dan mematuhi aturan main sang penguasa.

Eksistensi ulama dalam ruang politik praktis baik langsung ataupun tidak ternyata menimbulkan persoalan dan perdebatan yang tak kunjung berujung, dan lantas melahirkan fenomena sendiri dalam sejarah "perilaku" politik ulama dalam konteks kebangsaan. ${ }^{1}$

\footnotetext{
${ }^{1}$ Darwis Mazhar, Perilaku Politik Ulama dan Kyai dalam Sorotan, t.t., 5.
} 
Ulama sesungguhnya memiliki peran penting di tengah masyarakat. Ulama memiliki wibawa, kharisma dan dihormati masyarakat, karena keluhuran akhlaknya. Ulama dianggap sebagai benteng moralitas karena kesederhanaan dan kejujuran yang mereka lakukan. Bahkan secara sosiologis, kehadirannya dapat dipandang sebagai salah satu agen perubahan, sebab masyarakat, dalam banyak hal, hampir selalu mendasarkan kegiatannya pada petunjuk kiai. ${ }^{2}$

Keberpihakan ulama pada masyarakat bawah, membuat ulama selama ini terpelihara dengan baik, akibat kejujuran, keikhlasan dan kenetralan ulama ditengah masyarakat, ${ }^{3}$ masyarakat Indonesia dikenal sebagai masyarakat paternalistik. Masyarakat ini ditandai dengan kepatuhan yang tinggi kepada pemimpinnya.

Ulama sering kali diterjemahkan dengan pemaknaan yang sangat sempit dan terbatas bahkan sangat jauh meninggalkan semangat awalnya, sebagaimana dalam matan al-Bukhari ان العلماء ورثة الانبياء sesunggunya ulama adalah pewaris para Nabi). ${ }^{4}$ Akibatnya, makna ulama lantas hanya terbatas pada mereka yang mempunyai publik figur dengan simbol-simbol religius an sich, pemangku pondok pesantren. Ulama pada hakikatnya sebagai pewaris nabi dalam semua hal, tidak hanya menyangkut urusan agama, tetapi juga dalam urusan dunia, khususnya dalam menata kehidupan dan mewujudkan masyarakat thayyibatun wa rabbun ghofur.

Secara umum bisa dinyatakan ulama memiliki pengaruh terhadap kehidupan masyarakat. ${ }^{5}$ Pengaruh ulama

${ }^{2}$ Miftah Faridl, "Perilaku Sosial Politik Kiai di Tengah Masyarakat Transisi Kasus di Wilayah Cirebon dan Bandung," Mimbar XXI, no. 2 (Juni 2005): 166.

3 Hamdan Daulay, Dakwa di Tengah Persoalan Budaya dan Politik (Yogyakarta: LESFI, 2001), 85.

${ }^{4}$ Dalam konsep ini, secara teologis, masyarakat Muslim meyakini bahwa ulama merupakan pewaris para Nabi (waratsat al-anbiyâ) yang berfungsi sebagai pembimbing masyarakat, serta pemeran kharismatik dalam menegakkan ajaran amar ma'ruf nahy munkar, yang berusaha mewujudkan ajaran Islam dalam kehidupan bermasyarakat. Lihat: Faridl, "Perilaku Sosial Politik Kiai di Tengah Masyarakat Transisi Kasus di Wilayah Cirebon dan Bandung," 166.

5 Masruhan, "Pemikiran Kyai NU tentang Relasi Agama dan Negara," Jurnal Al-Qānūn 12, no. 1 (Juni 2009): 108. 
tidak hanya pada masyarakat awam tetapi juga merambah pada para pejabat atau tokoh partai politik. Dalam kenyataan empirik bahwa ulama banyak diperebutkan oleh orang yang menduduki jabatan politisi tertentu. Hingar bingar dan tarik menarik ulama dalam pemilu, pemilihan gubernur menandakan bahwa tarikan kepentingan politik ulama masih besar. ${ }^{6}$ Apalagi didukung dengan kenyataan mayoritas penduduk indonesia berasal dari kalangan nahdliyin.

Dari penggeseran wacana ulama ke politik banyak kontroversi tentang keterlibatan ulama dalam politik praktis. KH. Makrus Ali misalnya menentang ulama NU terjun dalam politik, karena banyak fakta yang berbicara ulama yang sibuk menyusuri politik praktis mengakibatkan bidang garap NU banyak terbengkalai, banyak kedudukan politik yang diperoleh NU ternyata tidak bermanfaat. ${ }^{7}$ Pendapat ini mengacu pada Keputusan Muktamar NU XXXVII 1984 bahwa NU tidak lagi berpolitik praktis secara langsung dan kembali ke Khittah 1926.

Argumen tentang ketidakpantasan ulama berpolitik, pada dasarnya dilandasi oleh kuatnya opini sepihak tentang sosok dan fungsi ulama yang telah menghegemoni pemikiran masyarakat secara turun-temurun. Hingga, banyak yang berargumen bahwa posisi ulama tidak pernah terkait dengan masalah-masalah diluar batas religius dan moralitas keagamaan. ${ }^{8}$

Secara umum, argumen-argumen yang menjadi dasar pemarjinalan peran ulama adalah: Pertama, ulama adalah pengayom dan teladan masyarakat. Sebab, selain sebagai

\footnotetext{
${ }^{6}$ Menurut Saoki, ini tak lepas dari paradigma relasi Islam dan negara. Di mana paradigma ini menjadi semakin mengemuka menjelang pemilu, karena momen ini merupakan kesempatan besar bagi semua golongan yang ingin memperjuangkan aspirasi politiknya, baik yang berideologikan nasionalis, maupun Islam. Lihat: Saoki, "Islam dan Negara Menurut M. Natsir dan Abdurrahman Wahid," Al-Daulah: Jurnal Hukum dan Perundangan Islam 4, no. 2 (Oktober 2014): 345.

7 Slamet Effendi Yusuf, Dinamika Kaum Santri: Menelusuri Jejak dan Pergolakan Internal NU (Jakarta: Rajawali, 1983), 130-36.

${ }^{8}$ Masruhan, “Pemikiran Kyai NU tentang Relasi Agama dan Negara," 102.
} 
pemegang otoritas keagamaan, ulama juga dianggap sebagai figure cultural (cultural figure) yang dekat dengan masyarakat bawah. Dikhawatirkan, paradigma sebagai cultural figure akan tergerus dan sirna ketika ulama memilih jalur politik sebagai aktivitas hidupnya. Kedua, posisi ulama sebagai penjaga moralitas masyarakat (morality figure) dikhawatirkan akan runtuh, ketika mereka terseret dalam pusaran dunia politik, sebab politik adalah dunia lain yang tidak pernah mengindahkan moral sebagai prinsip gerakan. ${ }^{9}$

Sebaliknya terdapat pendapat lain yang mengatakan bahwa tidak ada alasan ulama untuk meninggalkan politik praktis sebab berpolitik merupakan bagian dari kehidupan agama itu sendiri. ${ }^{10}$ Paling tidak ada beberapa alasan mengapa ulama sebagai pemuka elite agama terlibat dalam persoalan politik.

Pertama, bisa ditelusuri dari sumber ajaran agama Islam, yang memiliki lingkup tidak hanya aspek ritual dan bimbingan moral, tetapi juga pada nilai-nilai di semua sisi kehidupan baik dalam ilmu pengetahuan, ekonomi, hukum, sosial maupun persoalan politik. ${ }^{11}$ Sebagaimana juga di dalam ajaran Islam, selain sebagai pembawa risalah Rasulullah juga sebagai sosok negarawan sehubungan dengan posisinya sebagai kepala Negara. ${ }^{12}$

${ }^{9}$ Mazhar, Perilaku Politik Ulama dan Kyai dalam Sorotan, 12.

10 Apalagi Gus Dur dan K.H. Achmad Siddiq menyatakan bahwa Islam sebagai agama memberlakukan nilai-nilai normatif dalam kehidupan perorangan maupun kolektif, sedangkan negara tidak mungkin memberlakukan nilai-nilai yang tidak diterima oleh masyarakat yang berbeda-beda agama dan pandangan hidupnya. Lihat: Saoki, "Islam dan Negara Menurut M. Natsir dan Abdurrahman Wahid," 358.

11 Seperti yang dikatakan oleh al-Maudūdy, bahwa Islam bukan hanya sebagai suatu ajaran normatif tetapi juga sebagai ideologi yang komprehensif. Di dalamnya terkandung sistem ekonomi Islam, sistem politik Islam, sistem hukum Islam, dan lain-lain. Lihat: Abu Dzarrin al-Hamidy, "Landscape Pemikiran Abu alA'lā al-Mawdudi (1903-1979) Tentang Konsep Negara Islam," Jurnal al-Daulah 1, no. 2 (Oktober 2011): 208.

${ }^{12}$ Imam Suprayogo, Kyai dan Politik: Membaca Citra Politik Kyai (Malang: UIN-Malang Press, 2007), 2. 
Kedua, dilihat dari sisi sejarah. Peran politik ulama di Indonesia sejak lama terlihat, ${ }^{13}$ paling tidak sejak zaman Kesultanan Mataram II di Jawa. ${ }^{14}$ Keterlibatan ulama pada masa ini tidak hanya dilihat pada masa perlawanan fisik mengusir penjajah, tetapi juga, dalam kegiatan diplomasi. Baik ketika menjelang maupun setelah kemerdekaan diproklamasikan. Peran ulama lebih kentara tatkala sejumlah pesantren ditempatkan sebagai pusat strategi melawan penjajah, para ulama banyak memberikan dukungan moril, ekonomi dan politik.

Perjuangan ulama dalam waktu yang panjang masih berlanjut bahkan sebagian ulama ikut merintis dan mengembangkan organisasi Islam ditanah air seperti Masyumi, PSII, PETRI. Maka wajar jika ulama banyak dikenal sebagai pejuang, seperti KH. Hasyim Asy'ari, KH. Ahmad Dahlan, keduanya dikenal sebagai perintis organisasi besar di Indonesia-Nahdhotul Ulama dan Muhammadiyah. Dari kekuatan Islam yang besar tersebut dapat disimpulakan Islam harus dipahami sebagai kekuatan agama sekaligus kekuatan politik.

Ketiga, posisi ulama atau kyai sebagai elite agama memiliki massa (jamaah) dan pengaruh yang begitu luas kepada masyarakat, menjadikan mereka terlibat ke dalam persoalan pengambilan keputusan bersama, penyelesaian problem-problem sosial, pengembangan pendidikan dan kemasyarakatan. Secara sosiologis peran ulama di tengahtengah masyarakat seperti itu menjadikan posisinya sangat diistimewakan. Dari sisi ekonomi, status sosial mereka beragam tapi pada umumnya dari keluarga berada, bahkan ada pula dari kelompok bangsawan. Akumulasi dari status sosial dan kekayaan semacam itu di tambah luasnya

${ }^{13}$ Kiprah para ulama dalam perjalanan bangsa ini tidaklah kecil. Lewat Islamisasi yang dilakukan oleh para wali, umat Islam akhirnya menjadi mayoritas. Lihat: Ali Maschan Moesa, "Kiai NU dalam Peradigma Politik Kebangsaan," Al-Daulah: Jurnal Hukum dan Perundangan Islam 2, no. 1 (April 2012): 97.

14 Pradjarta Dirdjosanjoto, Memelihara Umat, Kyai di antara Usaha Pembangunan dan Mempertahankan Identitas Lokal di Daerah Muria (Jakarta: Gunung Mulia, 1994), 17. 
pengetahuan keagamaan mereka menjadikan ulama sebagai pemimpin yang kharismatik dan disegani.

Kelebihan ulama seperti itulah yang akhirnya membuat ulama dipercaya dan terlibat dalam politik, bahkan di tunjuk ataupun dipinang dalam pemilihan kepala daerah dan wakil kepala daerah sebagaimana yang berlangsung di Jawa Timur tahun. Karena, ulama diyakini dapat mempengaruhi pasang surut perolehan suara dalam Pemilihan Gubernur Jawa Timur, dengan dugaan bahwa calon gubernur yang didukung ulama, akan potensial didukung oleh masyarakat Jawa Timur yang notabennya masih kental dengan kultur pesantren. Dengan sikap politik yang signifikan selaras dengan sikap politik ulama, meski pergeseran situasi politik yang berkembang di kalangan ulama sangat mungkin turut mempengaruhi signifikan tersebut terganggu dalam tingkatan tertentu, akan tetapi sampai pada pemilihan gubernur Jawa Timur signifikasi tersebut tetap berada pada level berpengaruh.

Didukung dengan perubahan mendasar dalam pelaksanaan pemilihan kepala daerah sesuai dengan Undang-Undang Nomor 32 Tahun 2004 tentang Pemerintah Daerah dalam Pasal 56 sampai Pasal 119 memang mempunyai makna yang strategis dalam proses berdemokrasi. Undang-Undang pemda menggantikan Undang-Undang Nomor 22 tahun 1999 yang dalam masa berlakunya masih menggunakan mekanisme pemilihan kepala daerah dalam sistem perwakilan oleh DPRD. UndangUndang Nomor 32 Tahun 2004 dilakukan pemilihan langsung oleh rakyat, sesuai dengan Pasal 24 ayat (5): "kepala daerah dan wakil kepala daerah di pilih dalam satu pasangan secara langsung oleh rakyat di daerah yang bersangkutan". ${ }^{15}$ Ketentuan ini mengingat bahwa dalam Undang-Undang Nomor 22 Tahun 2003 tentang susunan dan

15 KPU Kota Surabaya, "Undang-undang No. 32 Tahun 2004 Tentang Pemerintahan Daerah," 2004, 22. 
kedudukan MPR, DPR, DPD, dan DPRD. Maka DPRD tidak lagi memiliki kewenangan untuk memilih kepala daerah. ${ }^{16}$

Secara terselubung, beberapa tokoh yang menjadi bakal calon gubernur telah melakukan pendekatan dengan beberapa ulama dan tokoh pesantren dengan variasi bentuk dalih pertemuan antara calon gubernur dengan kiai pesantren semisal silaturrahim, mendatangi acara keagamaan, hal ini memperlihatkan bahwa ketokohan kiai dan tokoh-tokoh pesantren masih menjadi lahan sosialpolitik andalan dalam membangun dukungan atau menjadi politik dari komunitas kepamoran dan kewibawaan seorang kyai. Yang akhirnya akan memecah belah umat untuk mendukung beberapa kandidat calon gubernur.

Dari penjelasan di atas timbul permasalahan yang patut dikupas secara teliti tentang posisi ulama dalam Pemilihan Gubernur Jawa Timur. Penelitian difokuskan pada: (1) mekanisme posisi ulama dalam Pemilihan Gubernur Jawa Timur, dan (2) analisa Fiqh Siyasah dalam konteks posisi ulama dalam Pemilihan Gubernur Jawa Timur.

\section{Metodologi Penelitian}

Penelitian ini merupakan penelitian hukum empiris. Data dikumpulkan dengan menggunakan teknik: intervie (wawancara), ${ }^{17}$ observasi (pengamatan), ${ }^{18}$ dan studi literatur/kepustakaan. ${ }^{19}$

${ }^{16}$ Menurut Muwahid, tentunya ini tak lepas dari politik hukum nasional. Terutama setelah UUD 1945 mengalami perubahan sebanyak empat kali, yang tentunya sistem ketatanegaraan Republik Indonesia juga mengalami perubahan. Lihat: Muwahid, "Sistem Ketatanegaraan Indonesia Pasca Amandemen UUD 1945," Jurnal Al-Qānūn 13, no. 2 (Desember 2010): 484.

${ }_{17}$ Proses percakapan dengan maksud mengetahui tata cara mekanisme pencalonan Gubernur dan wakil gubernur Jawa Timur di KPU Provinsi Jawa Timur

18 Dengan cara pengambilan data dengan alat indera (terutama mata), metode ini digunakan untuk mengamati proses pencalonan gubernur dan wakil gubernur Jawa Timur dan posisi ulama dalam pemilihan gubernur Jawa Timur.

${ }^{19}$ Mengkaji sumber-sumber literatur baik dari buku, arsip, koran maupun majalah yang berkaitan dengan manuver politik ulama ataupun tata cara pencalonan ulama dalam Pemilihan Gubernur Jawa Timur. 
Penelitian ini merupakan penelitian kualitatif, sehingga analisis data yang dipakai adalah diskriptif, yaitu prosedur pemecahan masalah yang diselidiki dengan menggambarkan atau melukiskan keadaan atau obyek penelitian tentang posisi ulama dalam pemilihan Gubernur Jawa Timur dalam prespektif fiqh siyasah. Selanjutnya data tersebut dianalisis menggunakan metode content analisis (analisis isi). ${ }^{20}$ Sedangkan dalam analisis fiqh siyasah guna menyimpulkan ide hukum ketatanegaraan Islam, maka penulis menggunakan pola fikir deduktif,, ${ }^{21}$ guna memperoleh kepastian arti (qot'iy al-Dalalah), kemudian secara induktif, guna menjelaskan tentang pemilihan kepala daerah dan wakil kepala daerah Jawa Timur 2008.

\section{Posisi Ulama dalam Pemilihan Gubernur Definisi ulama}

Definisi ulama dapat diklasifikasikan menjadi dua yakni definisi secara etimologi dan terminologi. Secara etimologi kata ulama berasal dari bahasa arab yang berupa jama' dari mufrod (kata tunggal) alima yang artinya orang yang berilmu. ${ }^{22}$ Sedangkan secara terminology (istilah) menurut Syaikh Muhammad Nawawi Ulama Banten Jawa Barat dalam bukunya Abdul Qodir Jaelani, Ulama didefinisikan kasyatullah mengenal Allah dalam pengertian

${ }^{20}$ Pola kerja "Analisis Isi" adalah menganalisis secara tuntas dan kritis makna sebuah teks. Menurut Klaus Krippenderrff content analisis adalah inferensi (kesimpulan makna) yang dapat ditiru (replicable) dan sahih data dengan memperhatikan bentuknya. Lihat: Klaus Krippenderrff, Analiisis Isi: Pengantar Teori dan Methodology, trans. oleh Farid Wajidi (Jakarta: Rajawali, 1991), 15.

${ }^{21}$ Membahas data-data yang bersifat umum berupa dalil-dalil baik dari alQur'an maupun Hadist tentang politik prespektif fiqh siyasah, pendapat para pakar fiqh siyasah dan data-data lainnya, kedalam topik yang sama tentang reposisi kepemimpinan ulama.

${ }^{22}$ Ulamā' merupakan jama' dari 'ālim. Dalam al-Qur'an, 'ālim diartikan sebagai "orang yang punya kelebihan berupa ilmu dan kadar kecerdasan yang dengan itu dia mampu mengeluarkan ayat-ayat Allah dan lebih menonjolkan penampilan keilmuwan sebagai orang yang berilmu (alim). Lihat: Abdurrohman, "Pertimbangan Hakim Pengadilan Negeri Mojokerto tentang Anak yang Melakukan Penganiayaan Menurut Hukum Islam," Al-Jinâyah: Jurnal Hukum Pidana Islam 2, no. 1 (Juni 2016): 26. 
yang hakiki, pewaris Nabi, pelita ulama dengan ilmu hasanah ketaqwaan dan istiqomah yang menjadi landasan baginya dalam beribadah dan beramal shaleh, selalu berlaku benar dan adil. ${ }^{23}$

Menurut Zamakhsyari Dhofier ulama adalah gelar yang diberikan masyarakat kepada orang yang ahli agama Islam yang memiliki atau menjadi pimpinan pesantren dan mengajar kitab-kitab klasik kepada santrinya, ${ }^{24}$ menurut Darwis Mazhar istilah ulama juga digunakan sebagai nama gelar bagi orang-orang yang ditokohkan oleh masyarakat dalam hal keagamaan. ${ }^{25}$

Menurut Bahrudin Subki, ulama sekurang-kurangnya harus memenuhi kriteria atau karakteristik sebagai berikut:

1. Menguasai ilmu agama Islam (tafaquh fiddin) dan sanggup membimbing umat dengan memberikan bekalbekal ilmu keislaman yang bersumber pada al-Qur'an dan Hadist.

2. Ikhlas melaksanakan ajaran Islam.

3. Mampu menghidupkan sunnah Rasul dan mengembangkan Islam secara kaffah.

4. Berakhlak luhur, berfikir kritis, aktif mendorong masyarakat melakukan perbuatan positif, bertanggung jawab dan istiqomah.

5. Berjiwa besar, kuat mental dan fisik, amanah serta tawakkal kepada Allah.

6. Mengetahui dan peka terhadap berbagai macam situasi zaman, sehingga mampu menjawab tiap permasalahan umatnya.

7. Berwawasan luas serta menguasai beberapa cabang ilmu demi pengembangan, penerimaan pendapat orang

${ }^{23}$ Abdul Qodir Jaelani, Peran Ulama dan Santri dalam Perjuangan Politik di Indonesia (Surabaya: Bina Ilmu, 1994), 3.

${ }^{24}$ Zamakhsyari Dhofier, Tradisi Pesantren: Studi tentang Pandangan Hidup Kyai (Jakarta: LP3S, 982), 55.

${ }^{25}$ Mazhar, Perilaku Politik Ulama dan Kyai dalam Sorotan, 24. 
lain yang tidak bertentangan dengan agama dan bersikap tawadu'.26

Fenomena kehidupan sosial menunjukkan bahwa telah terdapat empat tahap pergeseran makna ulama. Pertama, ulama dipahami sebagai orang-orang yang memiliki disiplin ilmu yang tidak hanya terbatas kepada bidang agama saja. Kedua, dipahami sebagai orang-orang yang hanya menguasai disiplin ilmu agama dalam berbagai aspek seperti tawhid, tasawuf dan fiqh. Ketiga, hanya terbatas kepada orang-orang yang memahami tentang hukum (fiqh). Keempat, ulama dipahami berdasarkan model pakaian yang digunakannya.

\section{Tipologi Ulama}

Prototipe ulama yang dikenal dimasyarakat menurut Imam Suprayogo dalam bukunya "Kyai dan Politik, mengklasifikasikan tipologi ulama menjadi empat kategori, sebagai berikut: ${ }^{27}$

1. Ulama spritual, yaitu ulama pengasuh pondok yang lebih menekankan pada upaya mendekatkan diri pada tuhan lewat amalan ibadah. Tipologi ulama seperti ini kurang peduli pada politik dan partisipasinya pasif.

2. Ulama advokatif, yaitu pengasuh pondok pesantren yang selain aktif mengajar para santri dan jamaahnya juga memperhatikan persoalan-persoalan yang dihadapi masyarakat dan senantiasa berusaha mencari jalan keluarnya. Tipologi ulama seperti ini menjadikan politik sebagai instrumen dan afiliasi politiknya tidak nampak.

3. Ulama politik adaptif yaitu pengasuh pesantren yang senantiasa peduli pada organisasi politik dan juga pada kekuasaan, ulama politik disebut sebagai kritis karena keberaniannya mengambil sikap berbeda dengan kekuatan dominan, sekalipun tidak beroposisi. Ulama advokatif hampir sama dengan ulama adaptif, tetapi

\footnotetext{
${ }^{26}$ Badrudin Subki, Dilema Ulama dalam Perubahan Zaman (Jakarta: Gema Insani Press, 1995), 47.

${ }^{27}$ Suprayogo, Kyai dan Politik: Membaca Citra Politik Kyai, 119-20.
} 
bedanya adalah jika ulama advokatif lebih dekat dengan rakyat maka ulama politik adaptif lebih dekat dengan penguasa.

4. Ulama mitra kritis mirip dengan ulama spiritual, tetapi memperhatikan dunia politik, dekat dengan umat, meletakkan kehidupan dunia dan akhirat secara seimbang.

Di luar itu, keberhasilan ulama dalam memimpin masyarakat, menjadikannya semakin tampak sebagai orang yang berpengaruh, termasuk dalam ranah politik, sehingga mampu mempengaruhi dan menggerakkan aksi atau tanggapan emosional para pengikutnya. ${ }^{28}$

Dalam perbincangan kepemimpinan, Usman melihat kepemimpinan ulama dari tiga kaca mata, ${ }^{29}$ yaitu dimensi legitimasi, dimensi pengaruh dan dimensi visibilitas. Yang di maksud dimensi legitimasi adalah melihat posisi pemimpin dari aspek legalitasnya. Pemimpin ini bisa berpengaruh dalam beberapa bidang sekaligus disebut kepemimpinan bersifat polimorphic, yang sering berkembang dalam masyarakat yang berstruktur kekuasaan monolitik. Tetapi bisa juga berpengaruh pada satu bidang yang disebut dengan kepemimpinan bersifat monomorphic. Dimensi ini lazimnya berkembang dalam struktur kekuasaan yang berkembang dalam masyarakat yang berstruktur kekuasaan pruralistik (majmuk).

\section{Posisi ulama dalam Pemilihan Gubernur}

Dalam pemilihan kepala daerah yang dilangsungkan di Jawa Timur, ulama menjadi rebutan politisi daerah untuk dipinang sebagai pendukung kebijakan birokrasi mereka. Ulama yang kebanyakan orang-orang NU menjadi rebutan kandidat calon gubernur (Cagub) Jawa Timur. Para cagub yakin dengan merangkul ulama yang notabennya tokoh NU akan meningkatkan perolehan suara dalam Pemilihan Gubernur (Pilgub) Jatim.

28 Abdurrohman, "Pertimbangan Hakim Pengadilan Negeri Mojokerto tentang Anak yang Melakukan Penganiayaan Menurut Hukum Islam," 26.

${ }^{29}$ Suprayogo, Kyai dan Politik: Membaca Citra Politik Kyai, 36. 
Kotornya dunia politik, sebenarnya tidak harus menjadikan ulama pasif untuk terjun di dalamnya, misi dakwah sangat mungkin disisipkan melalui aktivitas berpolitik. Walaupun tidak bergabung dalam partai politik tertentu yang mengusung orientasi "dakwah", para ulama yang politisi semestinya bisa menjadi pelopor dalam menjunjung etika berpolitik dikalangan politisi. ${ }^{30}$

Posisi lain ulama di luar calon yakni, menjadi "tim sukses". Di sini kepentingan para politisi akan dapat menyetir ketulusan ulama, karena di mata masyarakat ulama memiliki tingkat reputasi lebih tinggi ketimbang para politisi, posisi ulama untuk propaganda dan provokasi umat untuk mendukung pasangan mereka dengan berbagai dalih.

Bukti sejarah dalam perpolitikan di Indonesia menunjukkan bahwa tradisi dan kharisma ulama menjadi senjata ampuh untuk memobilisasi pengumpulan suara, sehingga menjadikan PPP menjadi partai yang cukup besar pada tahun $1971 .^{31}$ Namun, upaya pemarjinalan PPP terhadap ulama NU, membuat NU merasa dipermainkan dan dikecewakan. ${ }^{32}$

Akhirnya, melalui Munas Situbondo pada tahun 1983 dan Muktamar Surabaya 1984, NU kembali menjadi organisasi sosial keagamaan dan menyatakan kembali ke khittah. $^{33}$ Menurut Abdurrahman Wahid (Gus Dur), bahwa kembalinya NU ke khittah 1926 yang intinya ialah memisahkan NU dari politik dan bukan sebagai institusi. Artinya bahwa konsekuensi logis dari khittah adalah tidak ada politik Islam dan selanjutnya juga tidak ada lembaga politik Islam atau dengan kata lain menegaskan pentingnya lembaga politik Islam. ${ }^{34}$ Berangkat dari sikap politik ini maka ulama memiliki ruang gerak yang lebih leluasa untuk menyalurkan aspirasi politiknya pada organisasi politik apa pun.

\footnotetext{
${ }^{30}$ Daulay, Dakwa di Tengah Persoalan Budaya dan Politik, 84.

${ }^{31}$ Masruhan, "Pemikiran Kyai NU tentang Relasi Agama dan Negara," 102.

${ }^{32}$ Mazhar, Perilaku Politik Ulama dan Kyai dalam Sorotan, 120.

33 Abdul Munir Mulkhan, Runtuhnya Mitos Politik Santri (Yogyakarta: SIPRESS, 1992), 75.

${ }^{34}$ Moesa, "Kiai NU dalam Peradigma Politik Kebangsaan," 104.
} 
Adapula posisi ulama sebagai proker politik dalam pemilihan gubernur jawa timur, misalnya, seperti Abdurrahman Wahid merekomendasi Ahmady dari partai PKB. dan KH. Hasyim Muzadi yang menjadi pendukung di belakang Khofifah. pengaruh ulama tidak saja terbatas sebagai pemimpin keagaman, sebagaimana yang diungkapkan bahwa ulama bisa mempengaruhi pasang surut perolehan suara partai politik.

\section{Respon Ulama}

Ulama yang notebene sebagai penyangga moralrelegiuitas umat, dan secara emosional dekat dengan masyarakat, eksistensi mereka menjadi signifikan dalam setiap pemilihan, baik level lokal maupun nasional. Para calon saling berdatangan untuk menarik dukungan, dengan harapan suara umat yang ada dibelakangnya bisa mendongkrak kemenangan.

Sebagaimana dalam pemilihan gubernur, ulama diposisikan sebagai orang yang memiliki umat dan rakyat, ditempatkan sebagai penyangga kekuasaan-jabatan kadang menimbulkan konflik kepentingan dan kepercayaan. Sesunggunya sering kali agama dijadikan sebagai komoditas politik. Yang akhirnya membawa perpecahan persatuan bangsa karena umat beragama harus behadapan dengan umat beragama, yang berimplikasi pada terpecah belahnya umat.

Berbagai respon ulama dalam menanggapi keterlibatan elite penguasa dalam pemilihan gubernur Jawa Timur, sebagaimana yang di lakukan oleh PWNU Jawa Timur, organisasi yang tidak dibenarkan memihak, akan tetapi pasti terpengaruh dan tidak menginginkan terjadinya perpecahan. salah satu upayanya adalah mengadakan acara tanggal 21 Juli, dengan mengundang semua kandidat dan diminta menandatangani komitmet kesanggupan menampung aspirasi Nahdlotul Ulama bila nanti tetpilih menjadi gubernur. Artinya, siapapun yang menjadi gubernur NU akan membantunya, dapat dikatakan juga NU berpihak pada yang menang. 
Di sisis lain, sejumlah ulama yang mengklaim dirinya sebagai ulama salaf yang dipimpin oleh Gus Shalah mengeluarkan Deklarasi Tebuireng, sebagai salah satu respon terhadap perubahan politik yang terjadi dalam pemilihan gubernur, agar para ulama NU tidak terkotakkotak dalam beberapa kepentingan kelompok politik, empat poin deklarasi Tebuireng yaitu:

1. kembali ke khitoh perjuangan ulama salaf

2. Menjaga dan membentengi umat dari pengaruh liberalisme, pluralisme dan sekularisme dalam kaitan dengan agama serta aliran di luar Ahlu Sunnah wal jamaah

3. Mengajak Alim Ulama untuk meningkatkan silaturahim dan menjalin koordinasi dan komunikasi secara terus menerus.

4. Menegaskan kembali peran ulama untuk menjadi contoh dan mengajak umat untuk sungguh-sungguh menjalankan ajaran Islam.

\section{Analisa Fiqh Siyasah Terhadap Pelaksanaan Pemilihan Gubernur dan Wakil Gubernur di Jawa Timur}

Sistem pemilihan kepala daerah Jawa Timur secara langsung tertera dalam Undang-Undang Nomor 32 tahun 2004 Pasal 24 ayat (5): "kepala daerah dan wakil kepala daerah di pilih dalam satu pasangan secara langsung oleh rakyat di daerah yang bersangkutan". ${ }^{35}$ Mekanisme pengisian jabatan kepala daerah dengan sistem pemilihan langsung, belum pernah dipraktekkan dalam pemerintahan Islam, bahkan dalam skala yang lebih besar, mekanisme pengisian jabatan khalifah juga belum pernah dilaksanakan dengan sistem pemilihan langsung.

Pemilihan kepala daerah secara langsung memang bukan berasal dari praktek ketatanegaraan Islam. Sistem itu merupakan pranata modern yang diterapkan dalam ketatanegaraan Barat. Khususnya negara yang berbentuk

35 KPU Kota Surabaya, "Undang-undang No. 32 Tahun 2004 Tentang Pemerintahan Daerah." 
federal. Tetapi tidak juga menjastifikasi bertentangan atau diperbolehkan tanpa terlebih dahulu mengkaji nilai-nilai normatif dalam Islam.

Jika dikaji berdasarkan al-Qur'an, Sebagaimana firman Allah dalam surat an-Nisa' ayat 59, yang artinya: Wahai orang-orang yang beriman! Taatilah Allah dan taatilah Rasul(Muhammad). ${ }^{136}$

Dan firman-Nya, yang artinya: "Apa yang diberikan Rasul kepadamu, maka terimalah. Dan apa yang dilarangnya bagimu, maka tinggalkanlah." (QS. al-Hasyr (59): 7). ${ }^{37}$

Jadi, sistem-sistem di luar Islam boleh diadopsi selama tidak bertentangan dengan ajaran Islam. Sebagai contoh, perbuatan Nabi dalam menerima sistem di luar Islam adalah Nabi dan para sahabat menerima ketentuan aljiwär (pemberian suaka politik). Padahal sistem tersebut adalah sistem jahiliyah. Maka, Nabi lewat perbuatannya tersebut telah mengizinkan umatnya untuk menerima sistem-sistem di luar Islam yang tidak atau belum diterapkan dalam Islam sepanjang adanya manfaat dalam pandangan syari'at.

Dalam konteks ke-Indonesia-an sistem tersebut sudah disetting yang keberadaannya dimaksudkan sebagai alternatif yang paling rasional dan aman dalam perebutan kekuasaan. Sehingga sistem tersebut tersusun secara sistematis sebagai proses yang paling urgen dalam pelaksanaan pemilihan calon kepala daerah yang melalui beberapa tahapan yakni, penyelenggara pemilihan, pendaftaran pasangan calon, persyaratan secara adaministrasi pasangan calon, penetapan dan pengumuman pasangan calon.

Penyelenggara pemilihan sebagaimana Pasal 57 ayat (1) Undang-Undang Nomor 32 Tahun 2004 "pemilihan kepala daerah dan wakil kepala daerah diselenggarakan oleh

36 Departemen Agama Republik Indonesia, Al-Qur'an dan Tarjamah (Surabaya: Al-Hidayah, 2002), 128.

${ }^{37}$ Departemen Agama Republik Indonesia, 516. 
KPUD yang bertanggung jawab kepada DPRD".38 Secara esensial KPUD melaksanakan sebagian program dari DPRD. Maka, konsekwensinya lembaga tersebut harus diisi oleh orang-orang yang berkompeten dan mampu menyeleksi kandidat untuk memegang kekuasaan.

Dalam ketatanegaraan Islam lembaga ini belum dikenal, penyelenggara pemilihan dalam konteks negara adalah Ahl al-Hall wa al-Aqd (dalam istilah kontemporer adalah DPR) yang diberi wewenang khusus oleh khalifah itu sendiri, pememilihan dan pengangkatan amir (kepala daerah) dilaksanakan secara langsung oleh khalifah tanpa sistem perwakilan. Karena kholifah mempunyai otoritas penuh dalam menformulasikan kebijakannya. Kontrak yang ditawarkan khalifah harus diterima dan dilaksanakan oleh amir serta diakui secara defacto.

Tetapi pada masa umar pernah ia mengizinkan rakyat bermusyawarah memilih calon secara langsung. Sebagai contoh ketika mengangkat Ammar bin Yasir untuk menjadi gubernur Kufah, rakyatnya menolak Ammar. Menurut mereka, Ammar tidak memiliki pengetahuan dan kecakapan dibidang politik dan pemerintahan, dan tidak punya kemampuan untuk memikul tanggung jawab itu. Penolakan ini diterima oleh Umar, maka umar menempuh jalan musyawarah yang dilakukan oleh rakyat secara langsung.

Walaupun begitu tidak semua rakyat mempunyai hak pilih sebagaimana pemilihan langsung yang ada di Indonesia. Bahwa warga negara republik Indonesia yang sudah berumur 17 tahun mempunyai hak pilih dalam pemungutan suara pemilihan kepala daerah dan wakil kepala daerah.

Pada dasarnya pemilihan kepala daerah secara langsung sesuai dengan prinsip musyawarah dalam hukum ketatanegaraan Islam. hal ini seperti dituangkan dalam firman Allah dalam QS. al-Syura (42): 38, yang artinya "Maka

38 KPU Kota Surabaya, "Undang-undang No. 32 Tahun 2004 Tentang Pemerintahan Daerah." 
berkat rahmat Allah engkau (Muhammad) berlaku lemah lembut terhadap mereka. Sekiranya engkau bersikap keras dan berhati kasar, tentulah mereka menjauhkan diri dari sekitarmu. Karena itu maafkanlah mereka dan mohonkanlah ampun untuk mereka, dan bermusyawarahlah dengan mereka dalam urusan itu." ${ }^{\prime 39}$

Dan sabda Nabi saw.: "Kamu lebih mengetahui tentang urusan-urusan duniamu." (HR. Muslim). ${ }^{40}$

Di sini jelas bahwa dalam kaca mata fiqh siyasah penyelenggara pemilihan kepala daerah dalam Islam belum ada. Sistem pencalonan kepala daerah dalam Islam berbeda dengan apa yang tertera dalam Undang-Undang Nomor 32 Tahun 2004 sebagai acuan tata cara pencalonan kepala daerah dan wakil kepala daerah Jawa Timur.

Pendaftaran pasangan calon pemilihan kepala daerah dan wakil kepala daerah Jawa Timur harus melalui partai politik atau gabungan partai politik, Partai politik dan gabungan partai politik dapat mendaftarkan pasangan calon apabila memenuhi persyaratan memperoleh sekurangkurangnya $15 \%$ (lima belas persen) dari akumulasi perolehan suara sah dalam pemilihan umum anggota DPRD di daerah. Dalam Undang-Undang Nomor 32 Tahun 2004 juga mengakomodasi aspirasi dalam proses pendaftaran dan penetapan pasangan calon perseorangan.

Menurut Abdul Karim Zaidan, dalam Islam berdasarkan kaidah umum tidak diperbolehkan mencalonkan diri sendiri, tetapi diperbolehkan untuk mencalonkan orang lain atau dicalonkan karena tidak mengandung permintaan untuk menduduki suatu jabatan. ${ }^{41}$

Pendapatnya ini, didasarkan kepada hadits dari Abdurrahman bin Samirah, "Hai Abdurrahman bin Samurah, janganlah engkau meminta kekuasaan. Jika diberikan kekuasaan itu kepadamu karena sesuatu permintaan, maka engkau akan diwakilkannya (saja). Jika engkau diberi tanpa

${ }^{39}$ Departemen Agama Republik Indonesia, Al-Qur'an dan Tarjamah, 103.

${ }^{40}$ Muslim bin al-Ḥajjāj, Jämi' al-Ṣaḥih (Beirut: Dār al-Fikr, 1421), 823.

${ }^{41}$ Abdul Karim Zaidan, Masalah Kenagaraan dalam Pandangan Islam, trans. oleh Abd. Aziz (Jakarta: Yayasan Al Amin, 1984), 45-46. 
sesuatu permintaan, maka engkau telah ditetapkan untuk kekuasaan itu (ditolong)." (HR. al-Bukhari). ${ }^{42}$

Pelarangan pencalonan diri untuk menduduki suatu jabatan dalam hadits-hadits di atas, disebabkan orang yang meminta atau berambisi untuk menduduki suatu jabatan tidak bisa berlaku adil dan akan menimbulkan perbuatan kesewenang-wenangan yang didorong oleh ambisiusmenya tersebut.

Sebagaimana pendapat Maududi yang membenarkan pengisian jabatan kepala negara melalui pemilihan, tetapi tidak menyetujui rakyat yang mencalonkan diri. ${ }^{43}$

Disisi lain Abdul Karim Zaidan, menambahkan bahwa untuk zaman sekarang dikarenakan darurat dan demi kemaslahatan syari'at, maka diperbolehkan kepada seseorang mencalonkan dirinya sendiri untuk menduduki suatu jabatan. ${ }^{44}$ Pendapatnya ini dilandaskan pada tindakan Nabi Yusuf yang diceritakan Allah dalam al-Qur'an, yang artinya: "Dia (Yusuf) berkata: "Jadikanlah aku bendaharawan negeri (Mesir); Karena sesungguhnya aku adalah orang yang pandai menjaga dan berpengetahuan". (QS. Yusuf (12): 55). ${ }^{45}$

Menurut hemat penulis, Hukum Islam memperbolehkan pemeluknya mencalonkan diri dan dicalonkan untuk menduduki jabatan publik bagi yang merasa mampu untuk berlaku adil dan memangku jabatan sesuai dengan hakikat jabatan tersebut. Dengan alasan, pertama, hadits-hadits Nabi yang melarang pencalonan diri sebagaimana yang telah penulis sebutkan di atas, lebih diarahkan kepada pihak-pihak yang berambisi yang tidak mampu untuk berlaku adil. Jadi, untuk orang-orang yang mampu dan konsekwen serta bisa berlaku adil maka, tidak ada pelarangan dalam mencalonkan diri sebagai kepala daerah.

${ }^{42}$ Ibn Ḥajar al-'Asqalany, Fatḥ al-Bäry bi Sharh Șahih al-Imām al-Bukhāry, Jilid 13 (Beirut: Dār al-Fikr, t.t.), 123.

${ }^{43}$ Munawir Sjadzali, Islam dan Tatanegara: Ajaran Sejarah dan Pemikiran (Jakarta: UI Press, 1993), 176.

${ }^{44}$ Zaidan, Masalah Kenagaraan dalam Pandangan Islam, 46-47.

${ }^{45}$ Departemen Agama Republik Indonesia, Al-Qur'an dan Tarjamah, 357. 
Sedang para calon yang mendaftar harus memenuhi persyaratan sesuai dengan ketentuan Undang-Undang Nomor 32 tahun 2004 yakni: Bertaqwa kepada tuhan Yang Maha Esa, setia kepada pancasila, Undang-Undang Dasar Negara Republik Indonesia Tahun 1945, cita-cita proklamasi 17 agustus 1945, dan kepada NKRI serta Pemerintah, berpendidikan sekurangnya sekolah lanjutan tingkat atas atau sederajat, berusia sekurang-kurangnya 30 tahun, sehat jasmani dan rohani, tidak pernah dijatuhi hukuman penjara, tidak sedang dijabut hak pilihnya, Mengenal daerahnya dan dikenal masyarakat di daerahnya, Menyerahkan daftar kekayaan pribadi dan bersedia untuk diumumkan, Tidak sedang memiliki tanggungan hutang secara perseorangan dan atau secara badan hukum yang menjadi tanggung jawabnya yang merugikan keuangan negara, tidak sedang dinyatakan pailit, tidak perna melakuakan perbuatan tercela, Memiliki Nomor Pokok Wajib Pajak (NPWP), Menyerahkan bukti daftar riwayat hidup, Belum perna menjabat sebagai Kepala Daerah dan Wakil Kepala Daerah selama dua kali masa jabatan dalam masa jabatan yang sama, dan Tidak dalam status sebagai pejabat kepala daerah.

Dalam sejarah perpolitikan Islam tidak dijelaskan secara eksplisit syarat-syarat kepala daerah. Namun, kebanyakan kalangan berpendapat bahwa syarat-syarat kepala daerah (amir) sama dengan syarat-syarat yang harus dipenuhi oleh seorang imam (kepala negara). Dan persyaratan kepala daerah dalam Islam lebih dikedepankan pada poros keadilan, dalam menegakkan hukum Islam, selain itu juga Islam lebih mengedepankan segi kemampuan dalam berijtihad yang didasari dengan ilmu pengetahuan dan berwawasan luas yang memadai maupun kemampuan dalam mempertahankan wilayah.

Pemimpin dalam Islam memang diwajibkan bertaqwa kepada Allah dan kita dilarang mematuhi perintah orang-orang yang melewati batas, sesuai dengan ketentuan surat as-Syura' ayat 150-152, yang artinya: "Maka bertakwalah kepada Allah dan taatlah kepadaku, dan janganlah kamu mentaati perintah orang-orang yang 
melewati batas, yang membuat kerusakan di muka bumi dan tidak mengadakan perbaikan". 46

Baru pada masa Khalifah Umar bin Khattab membuat ketentuan persyaratan bagi kaum pejabat. Ketentuan dan persyaratan pertama diharuskan bagi seseorang yang diangkat jadi seorang pejabat membuat daftar harta kekayaan dan disimpan pada arsip negara. Setelah yng bersngkutan menjabat ternyata harta kekayaannya bertambah maka diserahkan pada baitul mal. Syarat tentang pendidikan seorang kepala negara harus mempunyai pengetahuan yang luas, yang menjadi perbedaan dengan peraturan tersebut adalah ukuran pendidikan yang dimiliki luas atau tidak dilihat dari pendidikan yang ditempuh.

Dari keseluruahan persyaratan dalam UndangUndang Nomor 32 Tahun 2004 sedikit banyak sudah diterapkan dalam persyaratan pengangkatan kepala daerah dalam Islam. Tetapi ada poin penting dalam sistem ketatanegaraan Islam yang tidak terdapat dalam ketentuan undang-undang bahwa syarat seorang imam itu harus berlaku adil sebagaimana syrarat-syarat yang dijabarkan oleh pemikir Islam pada zaman klasik, pertengahan dan kontemporer

\section{Analisa Fiqh Siyasah Tentang Posisi Ulama Dalam Pemilihan Gubernur dan Wakil Gubernur Jawa Timur}

Dalam pemilihan kepala daerah yang dilangsungkan di Jawa Timur. Posisi Ulama menjadi rebutan bagi politisi daerah untuk dipinang sebagai pemopang kebijakan birokrasi mereka. Ulama yang kebanyakan orang-orang NU di posisikan sebagai parameter. Karena, para cagub yakin dengan merangkul ulama yang notabennya tokoh NU akan meningkatkan perolehan suara dalam Pemilihan Gubernur (Pilgub) Jatim.

Dalam perspektif fiqh siyasah memang tidak ada penjelasan larangan bagi ulama mengambil bagian dalam berpolitik. Tetapi yang perlu diperhatikan adalah bagaimana

${ }^{46}$ Departemen Agama Republik Indonesia, 584. 
proporsinya yang tepat bagi para ulama sehingga tidak sampai menimbulkan implikasi yang negatif yang hanya merusak citra ulama itu sendiri. Ulama harus lebih bersikap selektif agar tidak terjatuh dalam lubang politik yang terkesan licik dan menyesatkan. Tetapi, ulama diharapkan sebagai lembaga kontrol sosial politik terhadap masyarakat atau pemerintah daerah agar kebijakan-kebijakan politik tidak menyimpang dari prinsip-prinsip agama dan menyampaikan misi dakwah lewat jalur birokrasi.

Dalam kacamata fiqh siyasah peran ganda Rasulullah, satu sisi sebagai rasul Allah dan pemimpin sebuah pemerintahan selama satu dasawarsa lebih telah membentuk integritas beliau sebagai umara dan juga ulama, meski demikian posisi baru beliau sebagai pemimpin pemerintah bukan berarti semua urusan duniawi menjadi hak paten Nabi Muhammad.

Posisi ulama dipercaya sebagai penjaga moral bangsa, menjadi panutan umat serta mempunyai legitimsi dari masyarakat. Karena pada satu sisi ulama harus fokus mengurusi masyarakat sedangkan pada sisi lain bertanggung jawab secara moral terhadap kebijakankebijakan pemerintah.

Ada dua alternatif bagi ulama non politisi dalam bersikap: Pertama, sikap netral-aktif, yaitu tidak berpihak kepada siapa pun, akan tetapi berusaha memperkenalkan profil dan agenda politik setiap calon kepada umatnya, untuk selanjutnya pilihan diserahkan secara penuh kepada masyarakat. Peran ulama seperti ini lebih efektif dalam mendidik masyarakat mengenal dunia politik dan membimbing mereka dalam menggunakan hak suara, tanpa harus berpihak pada satu calon. Kedua, netral-pasif, yaitu sama sekali tidak menyentuh lingkup politik dalam batas minimal sekalipun, artinya hanya mengayomi moralrelegiuitas umat saja yang menjadi perhatiannya, ulama yang bersikap demikian biasanya akan lebih diakui keikhlasannya oleh masyarakat.

Adapun dalam posisi ulama berpihak pada salah satu calon, hal terpenting yang perlu diperhatikan adalah 
berusaha meredam efek perbedaan ijtihad politik di kalangan masyarakat luas, artinya, perbedaan pandangan politik di antara ulama jangan sampai menimbulkan imbas terpecah belahnya umat. Tugas ulama dalam hal ini adalah: menggiring umatnya ke salah satu calon sambil mendewasakan mereka agar tidak konfrontatif terhadap calon dan pendukung lain

Memang di sini akan kelihata posisi startegis ulama. Ulama memiliki peluang untuk dapat memainkan peranannya secara maksimal dalam masyarakat, baik pada jalur bawah maupun jalur atas. Pada jalur bawah yang lebih mencerminkan partisipasi masyarakat, sedangkan pada jalur atas yang lebih bercorak formal sebagai salah satu upaya merealisasikan program pemerintah. ${ }^{47}$

Gus Mus, panggilan akrab Mustofa Bisri, Pengasuh Pondok Pesantren Raudlatul Tholibin, Rembang, mempunyai pandangan tidak masalah kyai atau ulama terjun dalam dunia politik sepanjang dalam konteks politik kebangsaan dan kerakyatan secara luas, bukan politik kekuasaan seperti yang terjadi saat ini. Peran kyai dan ulama akan lebih besar jika mereka masuk di dalamnya. Kyai dan ulama dapat melakukan peran sebagai pengontrol kebijakan-kebijakan pemerintah. Gus Mus sendiri lebih sepakat kalau untuk saat ini kyai atau ulama lebih banyak berperan di pesantren dan lembaga pendidikan. Tenaga, pikiran dan ilmu mereka lebih banyak dicurahkan untuk mendidik generasi muda kita. Bukan karena saya tidak senang pada para kyai atau membencinya, justru sebaliknya saya sangat menyayangi mereka, dunia politik saat ini masih berkubang pada kepentingan sesaat kekuasaan dan banyak intrik-intrik yang malah memperjelek citra mereka. ${ }^{48}$

Bila dicermati, kehadiran ulama dipanggung politik pilkada Jawa Timur dikarenakan empat faktor utama, yaitu:

\footnotetext{
${ }^{47}$ Faridl, "Perilaku Sosial Politik Kiai di Tengah Masyarakat Transisi Kasus di Wilayah Cirebon dan Bandung," 167.

48 Muiz, "Gus Mus: Kiai Boleh Berpolitik," diakses 8 Maret 2016, https://www.nu.or.id/post/read/9033/gus-mus-kiai-boleh-berpolitik.
} 
1. Kurangnya kepercayaan diri para politisi sipil akan kemampuan (diri dan partai) untuk mengelola dan menjadikan dirinya sebagai pemimpin publik.

2. Rapuhnya jaminan kekuasaan ditingkat konstitusi karena tidak lahir partai pemenang mayoritas di parlemen (DPR/MPR).

3. Menguatnya kontrol parlemen dan ekstra parlemen karena berkembangnya pendidikan politik di masyarakat.

4. Minimnya dukungan politisi bagi para cagub, sebagai konsekwensi hadirnya sistem multi partai yang tidak sederhana.

Oleh karena itu, ulama yang diposisikan memiliki umat dan rakyat ditempatkan sebagai penyangga kekuasaan-jabatan bagi mereka untuk mengegolkan duduk dalam kursi birokrasi. Kekuasaan politik yang lemah di tingkat parlemen akan terbantu oleh hadirnya ulama yang mempunyai masa dan kharismatik yang real, yang dalam hal ini adalah ormas-ormas Islam sebagai partai bayangan yang berkekuatan massa besar dan fanatik. Maka akan ada hubungan mutualisme yang saling menompang dan menguntungkan antar kedua belah pihak. Pihak politisi mendapatkan amunisi dan perlindungan, pihak ulama mendapat kesempatan dan kepercayaan.

Dalam pemilihan kepala daerah di Jawa Timur ini secara langsung dapat disimpulkan bahwa masyarakat kita masih melihat citra sosial partai dan citra tokoh partai sebagai sandaran dan alasan memilihnya. Artinya, barang siapa yang mampu mencitrakan partai dan tokohnya secara dekat dengan pemilih, maka kemungkinan akan dipilih semakin besar.

Dalam Islam, hampir semua ulama menyepakati bahwa pemimpin adalah abdi masyarakat. Sebagai representasi ulama, Nabi telah memerintahkan untuk mengangkat seseorang untuk menjadi pemimpin dalam suatu organisasi, baik yang kecil ataupun yang besar (masyarakat). Perintah ini diwajibkan, karena Tuhan telah memerintahkan kaumnya untuk melaksanakan amar ma'ruf 
nahi munkar, dan melalui pergerakan roda pemerintahan hal itu akan bisa berjalan secara sempurna.

Dan yang paling penting adalah dapat menjadi kontrol umaro/pemerintah dalam menjalankan tugasnya sebagai wakil rakyat. Indikator semacam ini akan mengangkat citra ulama sebagai hamba allah, yang paling patut di antara hamba-hambanya.

Sebagaimana firman Allah dalam QS. al-Fathir ayat 28, yang artinya: "Dan demikian (pula) di antara manusia, binatang-binatang melata dan binatang-binatang ternak ada yang bermacam-macam warnanya (dan jenisnya). Sesungguhnya yang takut kepada Allah di antara hambahamba-Nya, hanyalah ulama Sesungguhnya Allah Maha Perkasa lagi Maha Pengampun" ${ }^{49}$

Pada masa Rasulullah dan khulafaur Rosidin, banyak ulama yang diangkat untuk mengurusi urusan pemerintahan terutama menjadi amir (kepala daerah). Dalam negara Madinah Rasulullah membagi wilayah kekuasaan hukum menjadi beberapa propinsi, dan setiap propinsi menugaskan seorang amir atau wali (gubernur). Seperti, Itab bin Asid Amir untuk Makkah, amir yang diangkat pada masa nabi, Abu Musa al-Asy'ari amir untuk Zubaid dan Rima. Mereka adalah seorang ulama yang mempunyai pengetahuan luas, ahli agama dan banyak menghafal al-Qur'an dan Hadist. Setiap amir (gubernur) adalah wakil khalifah didaerah untuk melaksanakan tugas adminitrasi pemerintahan dan bertanggung jawab kepadanya.

Ini berarti politik agama harus diturunkan ke tingkat obyektif menjadi politik kelas dalam rangka mengakomodasikan kepentingan-kepentingan empiris umat dan bangsa. Hanya dengan inilah sebuah gerakan agama akan memiliki makna sejatinya sebagai gerakan untuk pembebasan struktural-suatu tugas yang dalam QS. Ali Imran (3): 110, yang artinya: "Kamu adalah umat yang terbaik yang dilahirkan untuk manusia, menyuruh kepada yang ma'ruf, dan mencegah dari yang munkar, dan beriman

\footnotetext{
${ }^{49}$ Departemen Agama Republik Indonesia, Al-Qur'an dan Tarjamah, 700.
} 
kepada Allah. Sekiranya Ahli Kitab beriman, tentulah itu lebih baik bagi mereka, di antara mereka ada yang beriman, dan kebanyakan mereka adalah orang-orang yang fasik. ${ }^{\prime 50}$

Pada masa dinasti mamluk hubungan ulama dana umara' bagai simbiosis mutualisme, posisi ulama di jadikan kekuatan untuk melindungi kebijakan-kebijakan pemerintah. Tidak sedikit dari mereka juga diangkat menjadi Qodi, amir disuatu daerah.

Dari posisi ulama dalam politik praktis, diharapkan ulama tidak meninggalkan tugas utamanya sebagai syi'ar agama. Namun keterlibatannya dalam politik praktis mengawal demokrasi yang lebih baik.

Namun dari sini bisa dilihat, dengan berdasarkan sikap politik kemasyarakatan tersebut dan sesuai dengan budaya politik Indonesia. Bahwa pemikiran politik para ulama, terutama para kyai NU selalu terbingkai pada sikap selektif, akomodatif, dan integratif dengan tetap memegang teguh nilai dan prinsip dasar yang telah ditetapkan. Sikap demikian diterapkan dalam rangka menjawab setiap permasalahan baru yang muncul dan mencarikan pemecahannya tanpa menimbulkan gejolak. ${ }^{51}$

\section{Penutup}

Berdasarkan uraian dan pembahasan sebelumnya, penulis dapat menarik beberapa kesimpulan, yaitu:

1. Mekanisme pengisian jabatan kepala daerah di Jawa Timur dengan sistem pemilihan langsung oleh rakyat. Dalam konteks inilah maka posisi ulama menjadi diperebutkan oleh para politisi, diarenakan ulama dianggap mempunyai legalitas, pengaruh dan modal sosial sebagai parameter yang dapat mempengaruhi pasang-surutnya perolehan suara dalam Pemilihan Gubernur Jawa Timur yang masih kental dengan kultur pesantren.

2. Dalam hukum ketata negaraan Islam tidak ada larangan ulama untuk mengambil bagian dalam kehidupan

\footnotetext{
${ }^{50}$ Departemen Agama Republik Indonesia, 94.

${ }^{51}$ Moesa, "Kiai NU dalam Peradigma Politik Kebangsaan," 115.
} 
berpolitik, karena Nabi disamping sebagai pembawa risalah Allah juga merangkap sebagai umara'. Pada Khalifa ar-Rasidun hampir semua lini jabatan pemerintah diduduki oleh para ulama.

\section{Daftar Pustaka}

Abdurrohman. "Pertimbangan Hakim Pengadilan Negeri Mojokerto tentang Anak yang Melakukan Penganiayaan Menurut Hukum Islam." Al-Jinâyah: Jurnal Hukum Pidana Islam 2, no. 1 (Juni 2016).

'Asqalany, Ibn Hajar al-. Fath al-Bäry bi Sharh Șahịh al-Imäm alBukhāry. Jilid 13. Beirut: Dār al-Fikr, t.t.

Daulay, Hamdan. Dakwa di Tengah Persoalan Budaya dan Politik. Yogyakarta: LESFI, 2001.

Departemen Agama Republik Indonesia. Al-Qur'an dan Tarjamah. Surabaya: Al-Hidayah, 2002.

Dhofier, Zamakhsyari. Tradisi Pesantren: Studi tentang Pandangan Hidup Kyai. Jakarta: LP3S, 982.

Dirdjosanjoto, Pradjarta. Memelihara Umat, Kyai di antara Usaha Pembangunan dan Mempertahankan Identitas Lokal di Daerah Muria. Jakarta: Gunung Mulia, 1994.

Faridl, Miftah. "Perilaku Sosial Politik Kiai di Tengah Masyarakat Transisi Kasus di Wilayah Cirebon dan Bandung." Mimbar XXI, no. 2 (Juni 2005).

Hajjāj, Muslim bin al-. Jämi' al-Sahih Beirut: Dār al-Fikr, 1421.

Hamidy, Abu Dzarrin al-. "Landscape Pemikiran Abu al-A'lā alMawdudi (1903-1979) Tentang Konsep Negara Islam." Jurnal al-Daulah 1, no. 2 (Oktober 2011).

Jaelani, Abdul Qodir. Peran Ulama dan Santri dalam Perjuangan Politik di Indonesia. Surabaya: Bina Ilmu, 1994.

KPU Kota Surabaya. "Undang-undang No. 32 Tahun 2004 Tentang Pemerintahan Daerah," 2004.

Krippenderrff, Klaus. Analiisis Isi: Pengantar Teori dan Methodology. Diterjemahkan oleh Farid Wajidi. Jakarta: Rajawali, 1991.

Masruhan. "Pemikiran Kyai NU tentang Relasi Agama dan Negara." Jurnal Al-Qänūn 12, no. 1 (Juni 2009).

Mazhar, Darwis. Perilaku Politik Ulama dan Kyai dalam Sorotan, t.t. Moesa, Ali Maschan. "Kiai NU dalam Peradigma Politik Kebangsaan." Al-Daulah: Jurnal Hukum dan Perundangan Islam 2, no. 1 (April 2012). 
Muiz. “Gus Mus: Kiai Boleh Berpolitik." Diakses 8 Maret 2016. https://www.nu.or.id/post/read/9033/gus-mus-kiaiboleh-berpolitik.

Mulkhan, Abdul Munir. Runtuhnya Mitos Politik Santri. Yogyakarta: SIPRESS, 1992.

Muwahid. "Sistem Ketatanegaraan Indonesia Pasca Amandemen UUD 1945." Jurnal Al-Qānūn 13, no. 2 (Desember 2010).

Saoki. "Islam dan Negara Menurut M. Natsir dan Abdurrahman Wahid." Al-Daulah: Jurnal Hukum dan Perundangan Islam 4, no. 2 (Oktober 2014).

Sjadzali, Munawir. Islam dan Tatanegara: Ajaran Sejarah dan Pemikiran. Jakarta: UI Press, 1993.

Subki, Badrudin. Dilema Ulama dalam Perubahan Zaman. Jakarta: Gema Insani Press, 1995.

Suprayogo, Imam. Kyai dan Politik: Membaca Citra Politik Kyai. Malang: UIN-Malang Press, 2007.

Yusuf, Slamet Effendi. Dinamika Kaum Santri: Menelusuri Jejak dan Pergolakan Internal NU. Jakarta: Rajawali, 1983.

Zaidan, Abdul Karim. Masalah Kenagaraan dalam Pandangan Islam. Diterjemahkan oleh Abd. Aziz. Jakarta: Yayasan Al Amin, 1984. 